\title{
Effectiveness Trichoderma and Beauveria bassiana on Larvae of Oryctes rhinoceros On Palm Oil Plant (Elaeis Guineensis Jacq.) In Vitro
}

\author{
Lita Nasution $^{1 *}$, Riahta Corah ${ }^{1}$, Nuraida ${ }^{1}$, Ameilia Zuliyanti Siregar ${ }^{2}$ \\ ${ }^{1}$ Dept Agrotechnology, Faculty of Agriculture, Al Azhar University Medan \\ ${ }^{2}$ Dept Agrotechnology, Faculty of Agriculture, Universitas Sumatera Utara
}

\begin{abstract}
O. rhinoceros horn beetle (Coleoptera: Scarabaeidae) is the main pest attacking oil palm crops in Indonesia, especially in palm oil rejuvenation areas. The study was conducted from April to August 2016 in the laboratory of the Faculty of Agriculture, Al-Azhar University, Medan. The materials used in this research are horn beetle pest larvae (O. rhinoceros) originating from PT. Socfin Indonesia, Trichoderma sp fungi originating from the Food Crops and Horticultural Fields of Medan and the B. bassiana fungi are derived from the Plant Seed Plant Protection Center (PBPPTP), aqua pro injection, Tween 80 , rice and $96 \%$ alcohol. This research uses Completely Randomized Design (RAL) Non Factorial consisting of 13 treatments. The result of mortality of $O$. rhinoceros larvae on 1-14 DAA observation can be seen in appendix 2-43. Based on fingerprint analysis showed that the application of Trichoderma sp and B. basianna fungi on O. rhinoceros larvae had no significant effect on observation of 1 DAA to 9 DAA, but had a very significant effect on observation of 10 DAA to 14 DAA. The results of germination of Trichoderma sp and B. basianna fungus 4 hours after incubation period can be seen in appendix 61-66. Precentages mortality of the highest larvae of $O$. rhinoceros to Trichoderma sp fungus with a dose of $20 \mathrm{gr}$ (96.67\%) with the application method spread on the larvae. The highest amount of conidial density is found in Trichoderma sp fungi with doses of $60 \mathrm{~g} \times 100-1 \mathrm{ml}$ of aqua pro injection of $7.25 \times 106$ conidia/ml.Germination level of conidia mushroom highest in Trichoderma sp fungi with dose $60 \mathrm{gr}$ $x$ 100-1 ml aqua pro injection that is as much as $91 \%$.
\end{abstract}

Keywords-Effectiveness, Trichoderma, Bauveria, Orycetes, Oil Palm Oil, Vitro.

\section{INTRODUCTION}

Palm oil is the most productive plant with the highest production of oil per hectare from other vegetable oil producers. Indonesia is the second largest palm oil producer in the world after Malaysia. As many as $85 \%$ more world market of palm oil is controlled by Indonesia and Malaysia [39]. One of the obstacles in the cultivation of oil palm crops is the pest attack that can cause damage to the plant to result in decreased levels of palm oil production. Pests can attack palm oil from the pre-nursery stage to the producing stage [23].

O. rhinoceros horn beetle (Coleoptera: Scarabaeidae) is the main pest attacking oil palm crops in Indonesia, especially in palm oil rejuvenation areas. These insects bore oil palm shoots which resulted in stunted growth and damage to the point of growing so deadly plants. In palm oil rejuvenation areas, horn beetle attacks can result in delays in palm oil production up to a year and dead plants may reach $25 \%$ [23]. Reducing the use of pesticides in agricultural areas requires the availability of other safe and environmentally friendly methods of control, such as by utilizing natural enemies, such as entomopathogenic fungi, predatory insects, and parasitoids [41].

Groups of fungi that infect insects are called entomopathogenic fungi. The famous entomopathogenic mushrooms are Namuraea rileyi, Metarizium anisopeliae and B. bassiana. B. bassiana (Balsamo) Vuillemin (Ascomycota: Hyphocreales) is a facultative entomopathogenic fungus with a wide range of hosts, besides this fungus has the potential to control more than 70 insect pests belonging to different orders, especially lepidoptera pests [18].

In addition, the use of antagonistic fungus is also an alternative control option because this method is considered safe for both users, consumers and the environment. An antagonist fungus that has been widely used as a biological controller is Trichoderma sp. Trichoderma sp mushroom cultures in applicative media such as bran can be given to the planting area and are bio decomposers as well as bio 
fungicides. Trichoderma sp also has a very effective biocontrol mechanism in suppressing the development of pathogens such as mycoparasitism, antibiosis, and competition [7].

$B$. bassiana fungi have been tried to control the $O$. rhinoceros pests in oil palm with concentration of $25 \mathrm{~g} \mathrm{ml}-1$ [32]. While Trichoderma sp fungus has been tried to control P. nicotianae disease on Deli tobacco plants with concentration of $20 \mathrm{~g} / \mathrm{L}$. Therefore, it is necessary to do research to find out the concentration of $B$. bassiana and Trichoderma sp fungi which is most effective to control horn beetle pest larvae on oil palm crop.

This study aims to determine the effectiveness of $B$. bassiana and Trichoderma sp fungi with different doses and methods of application to control horn beetle $(O$. rhinoceros) pest larvae in oil palm crops.

\section{METHOD}

Place and time of research

This research will be conducted at the Laboratory of the Faculty of Agriculture, Al-Azhar University, Medan. The study was conducted from April to August 2016.

\section{Materials and tools}

The materials used in this research are horn beetle pest larvae (O. rhinoceros) originating from PT. Socfin Indonesia, Trichoderma sp fungi originating from the Food Crops and Horticultural Fields of Medan and the $B$. bassiana fungi are derived from the Plant Seed Plant Protection Center (PBPPTP), aqua pro injection, Tween 80, rice and $96 \%$ alcohol.

The tool used in this research is haemocytometer, microscope, glass object, glass cover, hand sprayer, test tube, jar, kassa, erlemeyer, name label, beaker glass, scales, tube, aluminum foil and stationery.

\section{Research methods}

This research uses Completely Randomized Design (RAL) Non Factorial consisting of 13 treatments.

Where :

$\mathrm{T} 1=$ Trichoderma sp dose 20 gr B1 = B. bassiana dose 20 gr

$\mathrm{T} 2=$ Trichoderma $\mathrm{sp}$ dose 40 gr B2 $=$ B. bassiana dosage $40 \mathrm{gr}$

$\mathrm{T} 3=$ Trichoderma sp dose 60 gr B3 $=$ B. bassiana dose of $60 \mathrm{gr}$

$1=$ Application method is dispersed $2=$ Application method is sprayed
$($ Control $)=$ Provision of aqua pro injection

T11 = Trichoderma sp dosage 20 gr pertoples of dispersed application method.

T12 = Trichoderma sp dosage 20 gr x 100 ml-1 aqua pro injection pertoples application method is sprayed.

T21 = Trichoderma sp dosage 40 gr pertoples of dispersed application method.

T22 = Trichoderma sp dosage 40 gr x 100 ml-1 aqua pro injection pertoples application method is sprayed.

T31 = Trichoderma sp dose 60 gr pertoples of dispersed application method.

T32 = Trichoderma sp dose 60 gr x 100 ml-1 aqua pro injection pertoples application method is sprayed.

$\mathrm{B} 11=$ B. bassiana with a dose of $20 \mathrm{gr}$ peroples of dispersed application method.

$\mathrm{B} 12=$ B. bassiana with a dose of $20 \mathrm{gr} \times 100 \mathrm{ml}-1$ aqua pro injection pertoples application method is sprayed.

B21 = B. bassiana with a dose of 40 pertoples of dispersed application method.

$\mathrm{B} 22=$ B. bassiana with a dose of $40 \mathrm{~g} \mathrm{x} 100 \mathrm{ml}-1$ aqua pro injection pertoples application method is sprayed.

$\mathrm{B} 31=$ B. bassiana with a dose of 60 gr peroples of dispersed application method.

$\mathrm{B} 32=$ B. bassiana with a dose of $60 \mathrm{gr} \times 100 \mathrm{ml}-1$ aqua pro injection pertoples application method is sprayed.

Based on the treatment performed, the number of replications can be determined by the following formula (Hanafiah, 2010):

$\mathrm{t}(\mathrm{r}-1) \geq 15$

$13(\mathrm{r}-1) \geq 15$

$13 r-13 \geq 15$

$13 r \geq 15+13$

$13 r \geq 28$

$r \geq 28 / 13$

$\mathrm{r} \geq 2.15=3$ replications [12].

The amount of treatment is 13 treatments, among others:

T11 T12 T21 T22 Controls

T31 T32 B11 B12

B21 B22 B31 B32

But to further strengthen the results of research, then the replication used in the study is as much as 3 .

Based on the above description can be arranged the treatment unit as follows:

Treatment amount: 13 treatments

Number of repetition treatment: 3 replications

Number of research units: 39 units

Number of larvae per jar: 10 heads

Number of larvae tested: 390 heads

Distance between jars: $1 \mathrm{~cm}$ 
Distance between replicates: $15 \mathrm{~cm}$

Number of jars of Trichoderma sp: 18 jars

Number of jars of B. bassiana: 18 jars

Number of control jars: 3 jars

Total jars total: 39 jars

The mathematical model used in this research is the Non

Factorial Completely Randomized Design (Hanafiah, 2010)

which is assumed as follows:

Where:

$$
Y_{-} i j=\mu+N_{-} i+\varepsilon_{-} i j
$$

Y_ij: The results of observation of the treatment to the fungus and $\mathrm{j}$-thr

$\mu$ : Effect of middle value

N_i: Effect of $\mathrm{N}$ treatment on the mushroom stage

$\Sigma$ ij: Effect of errors from the treatment of fungi and jth thrust

If the treatment has significant effect, the Duncan test is $5 \%$ and $1 \%$.

\section{Implementation of Research}

Provision of larvae to be tested

Horned beetle larvae $(O$. rhinoceros) originating from PT. Socfin Indonesia was taken and maintained at Al-Azhar University Laboratory in Medan. The captured larvae are then adjusted in size and size to each other to obtain sufficient quantities to test. The larvae to be tested are instar larvae II.

\section{The supply of entomopathogenic fungi}

Trichoderma sp mushroom comes from Balai Proteksi Tanaman Pangan dan Hortikultura (BPTPH) Medan, while the fungus

B. bassiana is isolated from the pest of $O$. rhinoceros which is derived from Balai Besar Germination Plantation Crop Protection (BBPPTP) Medan. To anticipate the deficiency of the mushrooms that will be used then both mushrooms are propagated in the rice medium each containing 100 grams / pack and incubated at room temperature for 5-7 days. This mushroom removal is done in the incase to avoid contamination. In the event of contamination, re-purification by taking part of the uncontaminated fungus of $B$. bassiana and Trichoderma sp. To be grown on rice media until Trichoderma sp and $B$. bassiana are completely pure and uncontaminated.

\section{Application of Entomopathogenic Fungi}

Application is applied only once in a manner dispersed and sprayed with each type of fungus according to the treatment, on the control only by spraying aqua pro injection alone on instar larvae instar II. Then observed its development.
Observation Parameters

Percentage of Mortality

Observation of larval mortality started one day after application (DAA) weeks 14 days after application. The percentage of larval mortality was calculated by the formula:

$$
\mathrm{P}=\mathrm{a} / \mathrm{b} \times 100 \%
$$

Information:

$\mathrm{P}=$ Percentage mortality of $O$. rhinoceros $(\%)$

$\mathrm{a}=$ The number of $O$. rhinoceros is dead

$\mathrm{b}=$ Total $O$. rhinoceros observed entirely

If on the control found dead larvae then, the percentage of mortality obtained later in the correction using the Abbott's formula is as follows:

$$
\mathrm{P}=(\mathrm{Po}-\mathrm{Pc}) /(100-\mathrm{Pc}) \mathrm{x} 100 \%
$$

Where:

$\mathrm{P}=$ Percentage $O$. rhinoceros test that died after correction $\mathrm{Po}=$ Percentage of $O$. rhinoceros test that died at treatment $\mathrm{Pc}=$ Percentage of test dead $O$. rhinoceros in control

\section{Number of Conidia}

The number of conidia of entomopathogenic fungi is calculated before application is performed. Conidial density calculation was performed by suspension of conidia from isolation treatment of isolate taken as much as $1 \mathrm{ml}$. Then the suspension is dropped on haemocytometer. Conidial density was calculated under a 400x magnification binoculars microscope using Gabriel \& Riyatno [10] formula as follows:

$$
\mathrm{C}=\mathrm{t} /((\mathrm{n} \times 0.25)) \times 106
$$

Where:

$\mathrm{C}$ : Conidia density per $\mathrm{ml}$ of solution

$\mathrm{t}$ : Total number of conidia in the sample box observed

$\mathrm{n}$ : Number of sample boxes ( 5 large boxes $\mathrm{x} 16$ small squares)

0.25: Correction factor for use of small-scale sample boxes on haemocytometers

Conidia germination

The conidia granulation from each of the entomopathogenic fungi suspensions used was calculated before application was performed and after 24 hours of inoculation was performed. One drop of suspension of entomopathogenic fungus dripped on the glass object then drops with PDA media and closed with a glass cover, then the amount of 
germinated conidia is calculated, so it is not germinated. The calculations are performed on the field of view under a microscope with $400 \mathrm{x}$ magnification, using Gabriel \& Riyatno [10] formula as follows:

$$
\mathrm{V}=\mathrm{g} /((\mathrm{g}+\mathrm{u})) \times 100 \%
$$

Where:

V: Conidia germination (viability)

$\mathrm{g}$ : The number of conidia that germinate

$\mathrm{u}$ : The number of conidia that does not germinate

\section{RESULTS}

Percentage of Mortality

The result of mortality of $O$. rhinoceros larvae on 1-14 DAA observation can be seen in appendix 2-43. Based on fingerprint analysis showed that the application of Trichoderma sp and B. basianna fungi on $O$. rhinoceros larvae had no significant effect on observation of 1 DAA to 9 DAA, but had a very significant effect on observation of 10 DAA to 14 DAA. For more details can be seen in Tables 1,2 and 3.

Table.1: Average number of mortality Larva O.rhinoceros (\%) due to fungus Trichoderma sp and B. bassiana in the 1-5 Days After Application (DAA)

\begin{tabular}{ccccccc}
\hline \multirow{2}{*}{ Treatments } & \multicolumn{3}{c}{ Observation of day to- } & \multirow{2}{*}{ Mean } \\
\cline { 2 - 5 } & 1 DAA & 2 DAA & 3 DAA & 4 DAA & 5 DAA & \\
\hline Control & 0,00 & 0,00 & 0,00 & 0,00 & 10,00 & 2,00 \\
$\mathrm{~T}_{11}$ & 13,33 & 23,33 & 30,00 & 40,00 & 40,00 & 29,33 \\
$\mathrm{~T}_{12}$ & 10,00 & 13,33 & 23,33 & 30,00 & 33,33 & 22,00 \\
$\mathrm{~T}_{21}$ & 3,33 & 20,00 & 23,33 & 36,67 & 50,00 & 26,67 \\
$\mathrm{~T}_{22}$ & 3,33 & 6,67 & 13,33 & 20,00 & 23,33 & 13,33 \\
$\mathrm{~T}_{31}$ & 6,67 & 16,67 & 23,33 & 26,67 & 26,67 & 20,00 \\
$\mathrm{~T}_{32}$ & 0,00 & 0,00 & 0,00 & 13,33 & 23,33 & 7,33 \\
$\mathrm{~B}_{11}$ & 0,00 & 6,67 & 10,00 & 10,00 & 20,00 & 9,33 \\
$\mathrm{~B}_{12}$ & 16,67 & 23,33 & 30,00 & 30,00 & 36,67 & 27,33 \\
$\mathrm{~B}_{21}$ & 13,33 & 16,67 & 23,33 & 23,33 & 26,67 & 20,67 \\
$\mathrm{~B}_{22}$ & 13,33 & 13,33 & 13,33 & 23,33 & 26,67 & 18,00 \\
$\mathrm{~B}_{31}$ & 0,00 & 0,00 & 10,00 & 13,33 & 16,67 & 8,00 \\
$\mathrm{~B}_{32}$ & 13,33 & 13,33 & 20,00 & 23,33 & 26,67 & 19,33 \\
\hline Mean & 7,18 & 11,79 & 16,92 & 22,31 & 27,69 & 17,18 \\
\hline
\end{tabular}

The average number of mortality larvae of O. rhinoceros (\%) due to fungus Trichoderma sp and B. bassiana 6-9 Days After Application (DAA) in Table 2 . While the characteristics of O. rhinoceros larvae that died from Trichoderma sp and B. basianna fungi can be seen in Figs. 7 and 8.

Table.2: Average number of mortality Larva O. rhinoceros (\%) due to fungus Trichoderma sp and B. bassiana in the 6-9 Days After Application (DAA)

\begin{tabular}{cccccc}
\hline \multirow{2}{*}{ Treatmnets } & \multicolumn{4}{c}{ Observation day to -} & \multirow{2}{*}{ Mean } \\
\cline { 2 - 4 } & 6 DAA & 7 DAAA & 8 DAA & 9 DAA & \\
\hline Control & 10,00 & 10,00 & 20,00 & 20,00 & 16,67 \\
$\mathrm{~T}_{11}$ & 53,33 & 63,33 & 76,67 & 76,67 & 72,22 \\
$\mathrm{~T}_{12}$ & 43,33 & 46,67 & 50,00 & 56,67 & 51,11 \\
$\mathrm{~T}_{21}$ & 50,00 & 53,33 & 60,00 & 66,67 & 60,00 \\
$\mathrm{~T}_{22}$ & 30,00 & 33,33 & 36,67 & 56,67 & 42,22 \\
$\mathrm{~T}_{31}$ & 36,67 & 50,00 & 50,00 & 53,33 & 51,11
\end{tabular}




\begin{tabular}{cccccc}
\multirow{2}{*}{ Treatmnets } & \multicolumn{4}{c}{ Observation day to - } & Mean \\
\cline { 2 - 5 } & 6 DAA & 7 DAAA & 8 DAA & 9 DAA & \\
\hline $\mathrm{T}_{32}$ & 23,33 & 26,67 & 26,67 & 33,33 & 28,89 \\
$\mathrm{~B}_{11}$ & 26,67 & 36,67 & 56,67 & 60,00 & 51,11 \\
$\mathrm{~B}_{12}$ & 36,67 & 46,67 & 53,33 & 56,67 & 52,22 \\
$\mathrm{~B}_{21}$ & 26,67 & 33,33 & 43,33 & 60,00 & 45,56 \\
$\mathrm{~B}_{22}$ & 43,33 & 50,00 & 53,33 & 56,67 & 53,33 \\
$\mathrm{~B}_{31}$ & 16,67 & 33,33 & 46,67 & 63,33 & 47,78 \\
$\mathrm{~B}_{32}$ & 26,67 & 33,33 & 43,33 & 63,33 & 46,67 \\
\hline Mean & 32,56 & 39,74 & 47,44 & 55,64 & 47,61 \\
\hline
\end{tabular}

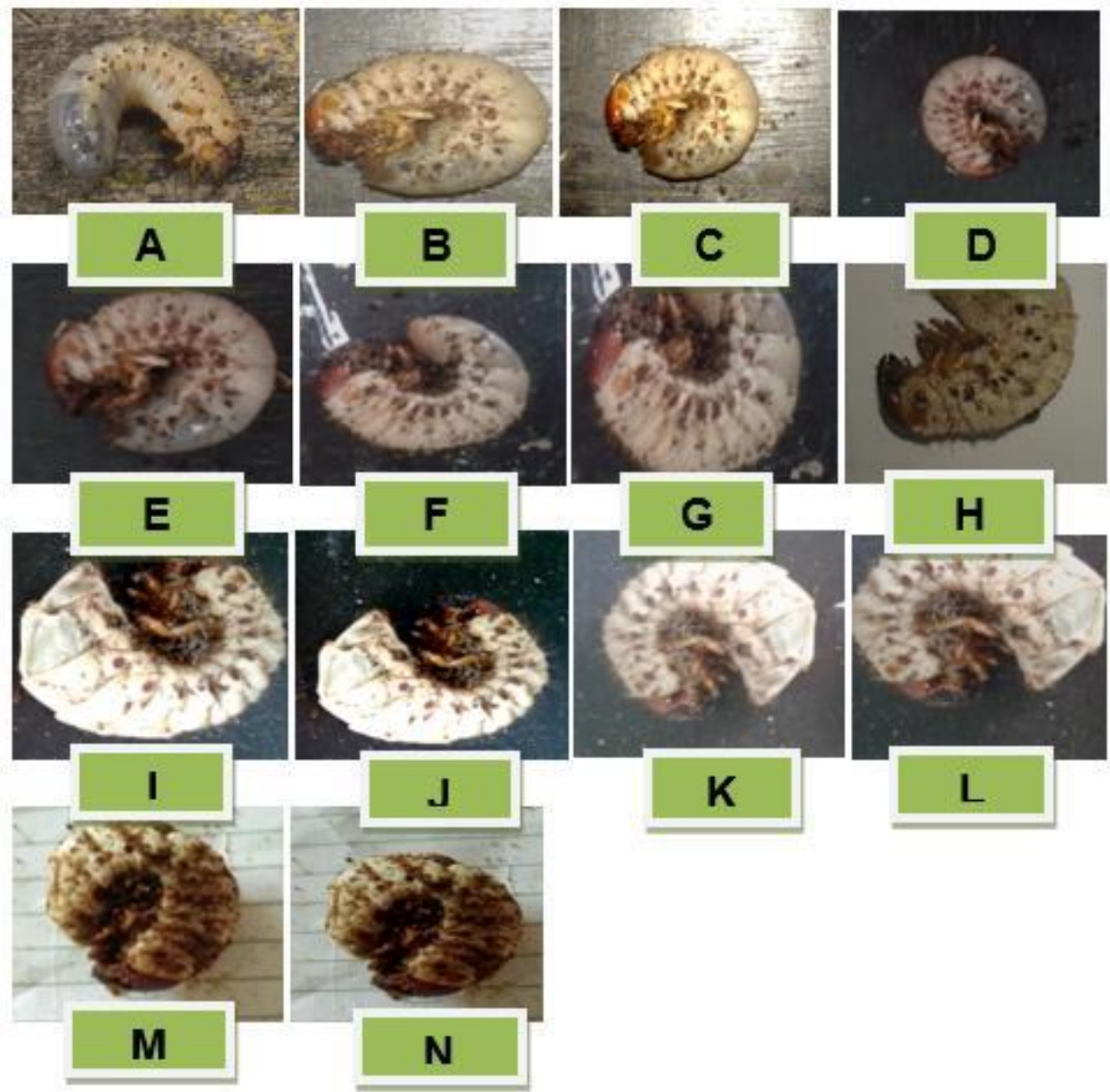

Fig.7: Symptoms of fungal infection of B. bassiana on Larvae of O. rhinocetos
A. Larvae attacked by the fungus $B$. bassiana 1 DAA
B. Larvae attacked by the fungus $B$. bassiana 2 DAA
C. Larvae attacked by the fungus $B$. bassiana 3 DAA
$D$. Larvae attacked by the fungus $B$. bassiana 4 DAA
E. Larvae attacked by the fungus $B$. bassiana 5 DAA
F. Larvae attacked by the fungus $B$. bassiana 6 DAA
G. Larvae attacked by the fungus $B$. bassiana 7 DAA 
H. Larvae attacked by the fungus $B$. bassiana 8 DAA

I. Larvae attacked by the fungus $B$. bassiana 9 DAA

A. Larvae attacked by the fungus $B$. bassiana 10 DAA

K. Larvae attacked by the fungus $B$. bassiana 11 DAA

L. Larvae attacked by the fungus $B$. bassiana 12 DAA

M. Larva attacked by the fungus $B$. bassiana 13 DAA

N. Larva attacked by the fungus B. bassiana 13 DAA

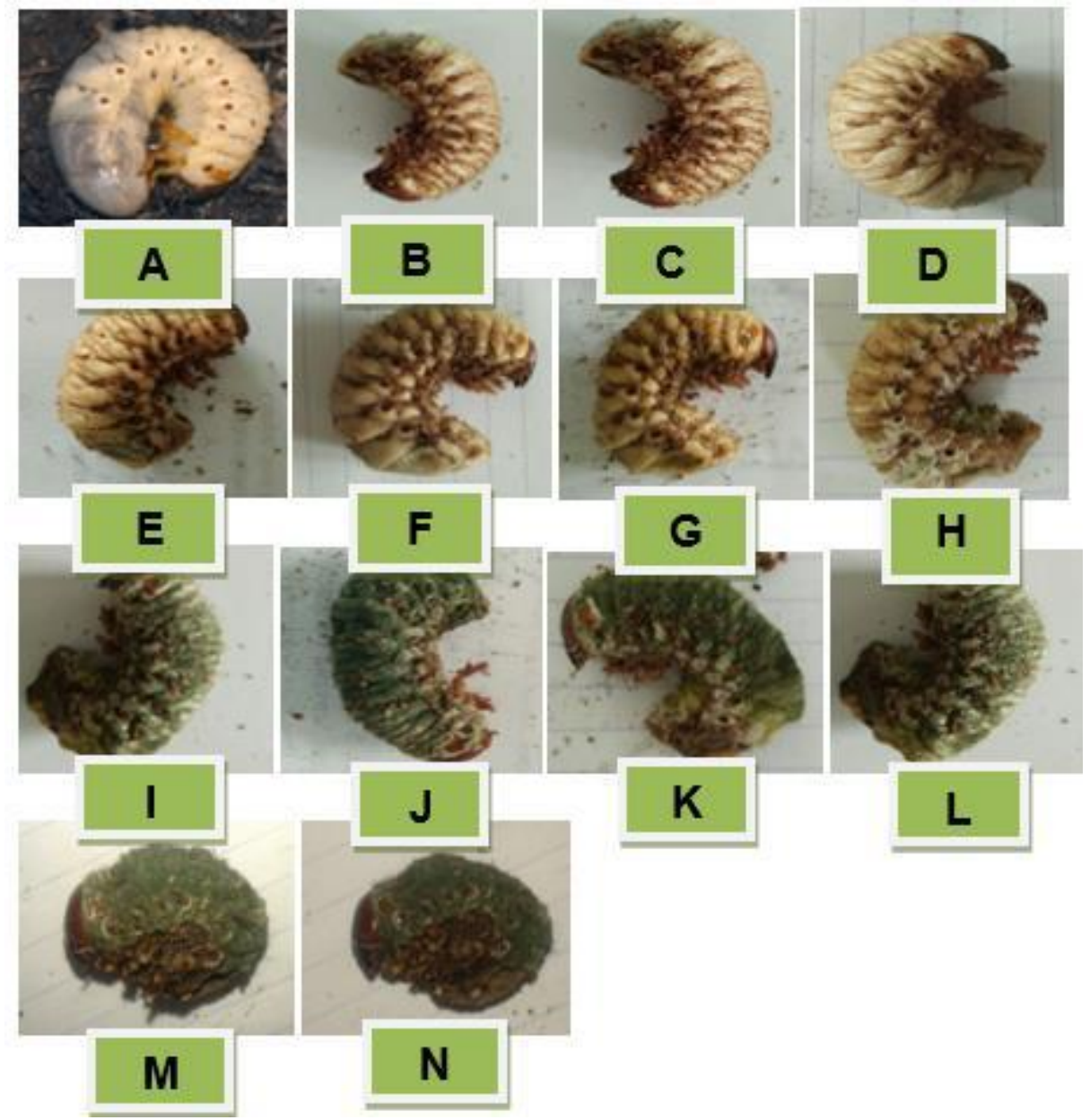

Fig.8: Symptoms of fungal infection of Trichoderma sp on Larvae O. rhinocetos
A. Larvae attacked by the fungus Trichoderma sp 1 DAA
B. Larvae attacked by the fungus Trichoderma sp 2 DAA
C. Larvae attacked by the fungus Trichoderma sp 3 DAA
D. Larvae attacked by the fungus Trichoderma sp 4 DAA
E. Larvae attacked by the fungus Trichoderma sp 5 DAA
F. Larvae attacked by the fungus Trichoderma sp 6 DAA
G. Larvae attacked by the fungus Trichoderma sp 7 DAA
H. Larvae attacked by the fungus Trichoderma sp 8 DAA
I. Larvae attacked by the fungus Trichoderma sp 9 DAA

A. Larvae attacked by the fungus Trichoderma sp 10 DAA

K. Larvae attacked by the fungus Trichoderma sp 11 DAA 
L. Larvae attacked by the fungus Trichoderma sp 12 DAA

M. Larva is attacked by the fungus Trichoderma sp 13 DAA

N. Larva is attacked by the fungus Trichoderma sp 13 DAA

From Table 3 it was found that in 10 DAA of Trichoderma sp and B. bassiana in T11 treatment was the highest mortality $(86.67 \%)$ and the lowest was in control (20\%). But the different T11 treatment was not significant with the treatments B21, B22, B31, B32, T12, T21, T22, T31, T32, B21, B22 and T11 differed markedly by control.

Table.3: Average number of mortality Pests Larvae O.rhinoceros (\%) due to fungus Trichoderma sp and B. bassiana 10-14 Days After Application (DAA)

\begin{tabular}{|c|c|c|c|c|c|c|}
\hline \multirow[t]{2}{*}{ Treatments } & & \multicolumn{4}{|c|}{ Obsert=vation day to- } & \multirow[t]{2}{*}{ Mean } \\
\hline & $10 \mathrm{DAA}$ & $11 \mathrm{DAA}$ & 12 HAS & $13 \mathrm{DAA}$ & $14 \mathrm{DAA}$ & \\
\hline Control & $20,00 \mathrm{bC}$ & $20,00 \mathrm{cC}$ & $20,00 \mathrm{cC}$ & $20,00 \mathrm{bB}$ & $20,00 \mathrm{bB}$ & 20,00 \\
\hline $\mathrm{T}_{11}$ & $86,67 \mathrm{aA}$ & $86,67 \mathrm{aAB}$ & $90,00 \mathrm{aA}$ & $93,33 \mathrm{aA}$ & 96,67 aA & 91,67 \\
\hline $\mathrm{T}_{12}$ & $73,33 \mathrm{abAB}$ & $76,67 \mathrm{abAB}$ & 83,33 aAB & $83,33 \mathrm{aA}$ & 96,67 aA & 85,00 \\
\hline $\mathrm{T}_{21}$ & $80,00 \mathrm{abA}$ & $90,00 \mathrm{aAB}$ & $90,00 \mathrm{aA}$ & $90,00 \mathrm{aA}$ & 93,33 aA & 90,83 \\
\hline $\mathrm{T}_{22}$ & $70,00 \mathrm{abAB}$ & $73,33 \mathrm{abAB}$ & $76,67 \mathrm{abAB}$ & $80,00 \mathrm{aA}$ & $90,00 \mathrm{aA}$ & 80,00 \\
\hline $\mathrm{T}_{31}$ & $60,00 \mathrm{bAB}$ & $63,33 \mathrm{bAB}$ & $66,67 \mathrm{abB}$ & $76,67 \mathrm{aA}$ & 83,33 aA & 72,50 \\
\hline $\mathrm{T}_{32}$ & $60,00 \mathrm{abAB}$ & $73,33 \mathrm{abAB}$ & $76,67 \mathrm{abAB}$ & $80,00 \mathrm{aA}$ & 83,33 aA & 78,33 \\
\hline $\mathrm{B}_{11}$ & $73,33 \mathrm{abAB}$ & $80,00 \mathrm{abAB}$ & 83,33 aAB & $83,33 \mathrm{aA}$ & 93,33 aA & 85,00 \\
\hline $\mathrm{B}_{12}$ & $76,67 \mathrm{abA}$ & $80,00 \mathrm{abAB}$ & $86,67 \mathrm{aAB}$ & $86,67 \mathrm{aA}$ & $90,00 \mathrm{aA}$ & 85,83 \\
\hline $\mathrm{B}_{21}$ & $83,33 \mathrm{aA}$ & $86,67 \mathrm{aAB}$ & $90,00 \mathrm{aA}$ & $90,00 \mathrm{aA}$ & 93,33 aA & 90,00 \\
\hline $\mathrm{B}_{22}$ & $83,33 \mathrm{aA}$ & $90,00 \mathrm{aA}$ & $90,00 \mathrm{aA}$ & $90,00 \mathrm{aA}$ & 93,33 aA & 90,83 \\
\hline $\mathrm{B}_{31}$ & $80,00 \mathrm{abA}$ & $86,67 \mathrm{aAB}$ & 86,67 aAB & $93,33 \mathrm{aA}$ & 93,33 aA & 90,00 \\
\hline $\mathrm{B}_{32}$ & $73,33 \mathrm{abAB}$ & $86,67 \mathrm{aAB}$ & 90,00 aA & $93,33 \mathrm{aA}$ & 93,33 aA & 90,83 \\
\hline Mean & 70,77 & 76,41 & 79,23 & 81,54 & 86,15 & 80,83 \\
\hline
\end{tabular}

Description: The numbers followed by the same letter in the same column show different results that are not real based on DMRT at $\mathrm{f}=5 \%$ and very different $1 \%$.

From observation 11 DAA showed that the highest mortality was in T21 and B22 (90\%) treatment and the lowest mortality was in control (20\%). This can be seen in Figures 9 and Figures 10 where T21 and B22 treatments differed not significantly on all treatments but differed significantly with controls.

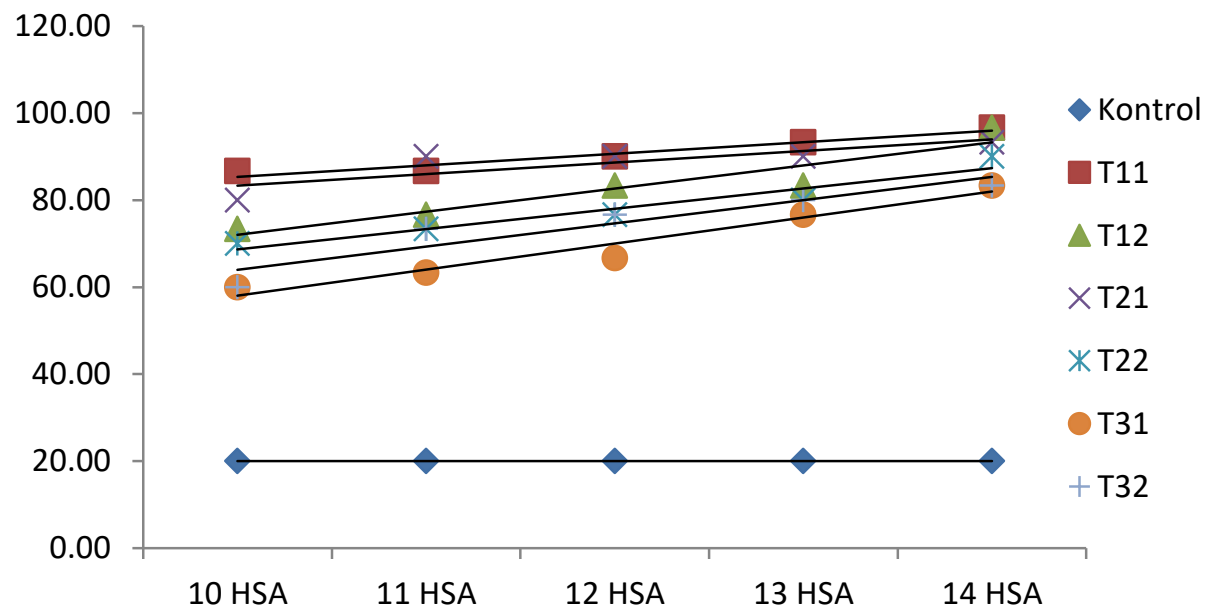

Fig.9: Percentage of Larvae Mortality O. rhinoceros After Application of Trichoderma sp 10-14 DAA. 


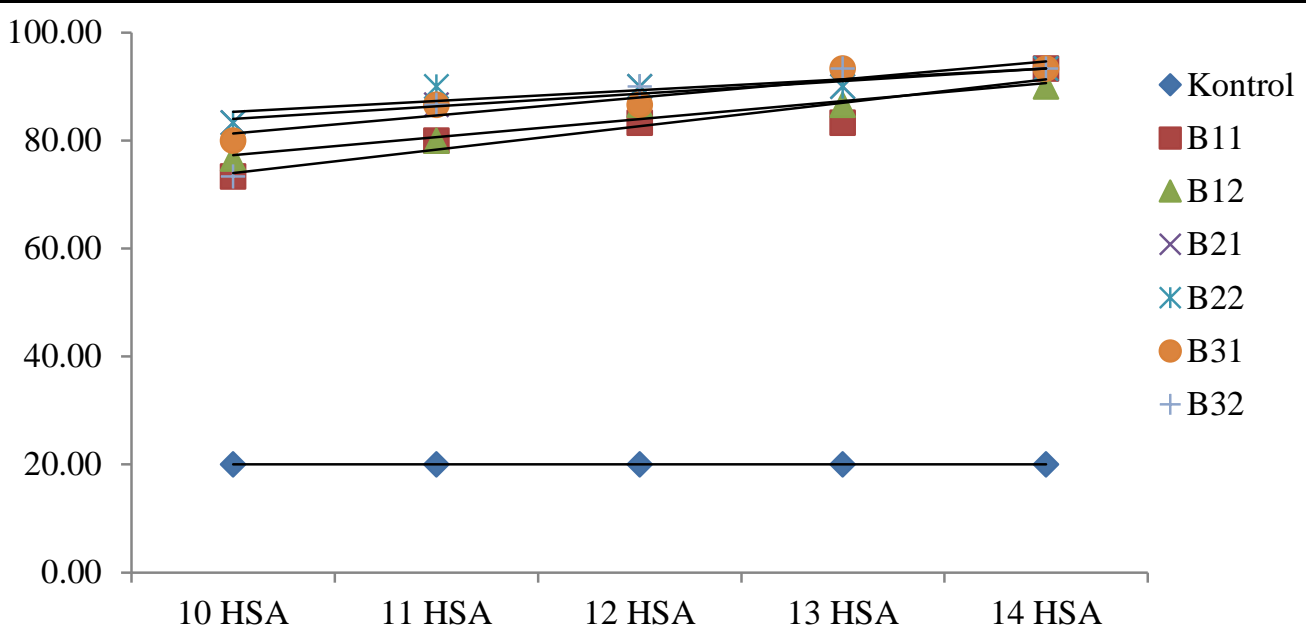

Fig.10: Percentage of Larvae Mortality O. rhinoceros after application of B. bassiana Fungus 10-14 DAA.

\section{Growth of Conidia}

Data from conidial density of entomopathogenic fungi Trichoderma sp and B. basianna can be seen in appendix 43-60. After the data were analyzed the density was known that the density of conidia from both entomopathogenic fungi showed a difference of Table 4.

Table.4: Conidial density of Trichoderma sp and B. basianna with various doses per ml of aqua pro injection

\begin{tabular}{|c|c|c|c|c|}
\hline \multirow{2}{*}{ Types of fungus } & \multirow{2}{*}{ Doses } & \multicolumn{3}{|c|}{ Spore density } \\
\hline & & $10^{8}$ & $10^{7}$ & $10^{6}$ \\
\hline \multirow{3}{*}{ Trichoderma sp } & $20 \mathrm{gr} \times 100-^{1} \mathrm{ml}$ & $4,75 \times 10^{6}$ & $5,32 \times 10^{6}$ & $5,85 \times 10^{6}$ \\
\hline & $40 \mathrm{gr} \times 100^{-1} \mathrm{ml}$ & $5,60 \times 10^{6}$ & $6,22 \times 10^{6}$ & $6,45 \times 10^{6}$ \\
\hline & $60 \mathrm{gr} \times 100^{-1} \mathrm{ml}$ & $7,25 \times 10^{6}$ & $6,89 \times 10^{6}$ & $5,25 \times 10^{6}$ \\
\hline \multirow{3}{*}{ B. bassiana } & $20 \mathrm{gr} \times 100-{ }^{1} \mathrm{ml}$ & $5,52 \times 10^{6}$ & $4,38 \times 10^{6}$ & $4,22 \times 10^{6}$ \\
\hline & $40 \mathrm{gr} \times 100^{-1} \mathrm{ml}$ & $5,95 \times 10^{6}$ & $5,12 \times 10^{6}$ & $4,68 \times 10^{6}$ \\
\hline & $60 \mathrm{gr} \times 100^{-1} \mathrm{ml}$ & $6,33 \times 10^{6}$ & $5,20 \times 10^{6}$ & $4,85 \times 10^{6}$ \\
\hline
\end{tabular}

The results of germination of Trichoderma sp and B. basianna fungus 4 hours after incubation period can be seen in appendix 61 66. After the data were analyzed, it was found that germination of conidia from both entomopathogenic fungi showed differences in Table 5 .

Table.5: Conidia germination of Trichoderma sp and B. basianna with various doses per ml of aqua pro injection

\begin{tabular}{lccc}
\hline & \multicolumn{3}{c}{ Total spore } \\
\cline { 2 - 4 } Types of fungus & $20 \mathrm{gr} \times 100-1 \mathrm{ml}$ & $40 \mathrm{gr} \times 100^{-1} \mathrm{ml}$ & $60 \mathrm{gr} \times 100^{-1} \mathrm{ml}$ \\
\hline Trichoderma $\mathrm{sp}$ & $76 \%$ & $83 \%$ & $91 \%$ \\
B. basianna & $77 \%$ & $80 \%$ & $85 \%$ \\
\hline
\end{tabular}

\section{DISCUSSIONS}

\section{Percentage of Mortality}

From Table 1 it can be seen that in observation 1 DAA has seen mortality in $O$. rhinoceros larvae, but the mortality is still relativelay low. This low mortality due to fungal conidia that enter and infect is still not maximal, because the fungi entering entomopathogen to infect the insects have a time span, otherwise the fungus of entomopathogen infects and deadly $O$. rhinoceros larvae is highly dependent on the amount of environmental conidia and nutrients that needed. As stated by [25,29] the ability of entomopathogenic fungi to kill larvae is highly dependent on environmental conditions, nutritional fit, $\mathrm{pH}$, from where the fungus grows and develops. 
From Table 2 on observations 6 DAA to 9 DAA mortality of $O$. rhinoceros larvae increased even though the different treatments were not real. But the mortality of larvae is still low, both due to the fungus Trichoderma sp and B. bassiana slow development of the fungus is due to the nutrients that the body is less available. This is in accordance with the stated by [15] states that the development of entomopathogenic fungi influenced the nutritional content of growing media used.

The Table 3 description of the occurrence of differences in mortality rates against $O$. rhinoceros larvae is caused by the number of conidia or concentration of conidia germination as well as different application methods. In this case the more the number of conidia that enter the body of the larvae and the germination of the high, then the death of the larvae will be faster. In addition, the number of conidia that enter the body of the larvae is also influenced by the method of application. Application with the spread method, then conidia that can enter into the body of the larvae will be more and more. Because the conidia that the application does not exist or very few are not on target. Whereas when the application with spray method the possibility of drift is large enough so that the conidia that concerns the body of the larvae is less. This is consistent with that stated by $[32,34]$ also states that, sooner or later mortality in pests depends on the amount of dose used.

This indicates that the application of Trichoderma sp and $B$. bassiana fungi with the same dosage applied sprinkled differently is not real by spraying either at the beginning of the observation or until the end of the observation. This is due to conidia applied from both types of fungi the germination and the power of the infection are both high. So the mortality of larvae is also high, as stated by $[3,36,36]$ that the higher dose conidia used in the treatment, the larval mortality is also high.

From observation 12 DAA showed that the highest mortality was in T11, T21, B21, B22 and B32 treatment (90\%) and the lowest mortality was in control (20\%). The treatments T11, T21, B21, B22 and B32 were not significantly different for all treatments but differed significantly with the controls. The high mortality of larvae other than influenced by the amount of conidia is also influenced by temperature/humidity. This is in accordance with the results of [32] study that the optimal temperature for Trichoderma sp growth ranges from $22^{\circ} \mathrm{C}-27^{\circ} \mathrm{C}$. Meanwhile, according to [1] that germination, growth and optimal sporulation of $B$. bassiana fungi occur at temperatures $25-30^{\circ} \mathrm{C}$.
From observation 13 DAA showed that the highest mortality was in T11, B31 and B32 treatment (93.33\%) and the lowest mortality was in control $(20 \%)$. Treatments of T11, B31 and B32 were not significantly different for all treatments but differed significantly with controls. This suggests that the density of conidia effectively controls the mortality of the $O$. rhinoceros larvae. At a higher level of conidia density, more and more mycelium and conidia grow. This is in accordance with [37] assertion that it increases the occurrence of conidial contact with the body of the larvae, thereby providing a better chance for conidia to stick, germinate and penetrate into the body of the larvae. From the 14 DAA observations it was found that T11 and T12 (96.67\%) and B11, B21, B22, B31 and B32 (93.33\%) were the highest mortality and the lowest was in control (20\%). However, the treatments of T11 and B11 differed significantly from the treatment of T12, T22, T22, T31, T32, B12, B21, B22, B31, B31, T11 and B11. This is because the longer the entomopathogenic fungi are in the body of the larvae, the amount of conidia increases. Damage to body tissue larvae due to fungus attacks will be more severe, so that the mortality rate of larvae will be higher. This is in line with the statement $[19,38]$ the longer the contact time of entomopathogenic fungi and host, the more likely the entomopathogenic fungus to infect the host, resulting in an increase in larval mortality.

From the observation in Fig. 9-10 it is also found that infected entomopathogenic larvae indicate a change in which the larval body becomes hard, mummification and the appearance of fungal conidia around the conidia color tube will appear in accordance with the color of the infecting conidial fungus. This is in line with [37] statement that infected insects of entomopathogenic fungi undergo mummification and after a few days will grow a colony of white-colored fungus around the body. At the beginning of death the larvae have not shown any change. While on the third day the larvae have begun to experience a change in color, where conidia mushrooms have begun to grow on the side of the larvae. On the fifth day until the larval larvae infected the body the larvae are fully satisfied by the entomopathogenic fungal conidia.

\section{Growth of Conidia}

Conidia density

Table 4 shows that the highest conidial fungus, Trichoderma sp with dose of $60 \mathrm{gr} \times 100-1 \mathrm{ml}$ of aqua pro injection, is $7.25 \times 106$ conidia / $\mathrm{ml}$ and the lowest conidial density is found in fungus $B$. basiaana at a dose of $20 \mathrm{gr} x$ $100-1 \mathrm{ml}$ aqua pro injection as much as 4.22106 conidia/ 
$\mathrm{ml}$. If seen from the number of doses can be concluded that, the higher the dose the number of conidia will also be higher.

\section{Conidia germination}

Table 5 shows that the number of conidia of Trichoderma sp fungi is higher than that of B. basianna. The conidia growth difference of each of these fungi may be caused by unequal nutrients. Each genus or fungal species requires nutrients, $\mathrm{pH}$, water content in medium, optimal temperature, light, aeration, and different incubation periods for growth and development of conidia [24,25,42]. The percentage of conidial germination is also influenced by the amount of conidia and conidial germination. The higher the amount of conidia and higher germination, the faster the mortality of the larvae. As stated by [43] that the higher dose conidia used in the treatment, the more rapid the death.

\section{CONCLUSIONS}

From result of research can be concluded that:

1. Precentages mortality of the highest larvae of $O$. rhinoceros to Trichoderma sp fungus with a dose of 20 gr $(96.67 \%)$ with the application method spread on the larvae.

2. The highest amount of conidial density is found in Trichoderma sp fungi with doses of $60 \mathrm{~g}$ x 100-1 ml of aqua pro injection of $7.25 \times 106$ conidia/ml

3. Germination level of conidia mushroom highest in Trichoderma sp fungi with dose $60 \mathrm{gr} \times 100-1 \mathrm{ml}$ aqua pro injection that is as much as $91 \%$.

\section{SUGGESTIONS}

To know the effectiveness of the fungus Trichoderma $\mathrm{sp}$ and B. bassianna need dilakuakn further research on application fungus of Trichoderma sp and B. bassianna directly to the field.

\section{REFFERENCES}

[1] Ahmad, RZ. 2008. Utilization of Fungi to Increase Productivity and Animal Health. J. Agricultural Research and Development 27: 84-92.

[2] Apriyaldi, R. 2015. Intensity Analysis of Horse Attack of Horn Beetle (Oryctes rhinoceros) In Palm Oil Plantation at PTPN V Sei Galuh Kampar Regency of Riau Province. Final Project.12-17.

[3] Bai NS, TO Sasidharan, OK Remadevi, PD Rajan, M Balachander. 2010. Virulence of Metharhizium Isolates Against The Polyphagous Defoliator Pest,
Spilarctia oblique (Lepidoptera: Arctiidae). J. Trop. Forest Sci. 22 (1) : 74-80.

[4] Barron. 2011. Beauveria bassiana. (Uoguelph.ca/-g barron/Miscelineous). Retrieved 20 April 2011.

[5] Budi, AS, Afandhi, A and Puspitarini, RD. 2013. Pathogenicity of Entomopathogenic Fungus of Beauveria bassiana Balsamo (Deuteromycetes: Moniliales) On Spodoptera Larva litura Fabricius (Lepidoptera: Noctuidae). Journal of Plant Pests 1 (1): 57-65.

[6] Brotodjojo, R.R and Solichah, C. 2012. Effectivity of Entomopathogenic Fungus Beauveria bassiana to Control White Grub Lepidiota sp. 1-10.

[7] Chamzurni T, Oktarina H, and Hanum, K. 2013. Effectiveness Trichoderma harzianum and Trichoderma virens To Control Rhizoctonia solani Kuhn On Chili Seed (Capsicum annum L.). Agrista Journal 17 (1): 12-17.

[8] Clarkson Charnley. 2013. Boophilus Microplus Infection by Beauveria amorpha and Beauveria bassiana: SEM Analysis and Regulation Of SubtilisinLike Proteases and Chitinases. Current Microbiol 5: 257-261.

[9] Dinata, AJ. 2012. Pathogenic Fungi and Bacteria. Common Wealth Agricultural Bureaux. England. 233.

[10] Effendi, TA, Septiadi, R, Salim, A, Mazid, A. 2010. Fungi Entomopatogen Origin of Lebak Land in South Sumatra and its Potential as Biological Agent of Walang Sangit (Leptocorisa oratorius (F.) Journal of Tropical Plant Disease Pest (2): 154-191 ISSN 14117525.

[11] Gandjar. 2012. Atlas of Entomophatogenic Fungi. Springer- Verla. New York. 187.

[12] Hanafiah, K.A. 2010. The Design of Theory and Application Trials. Jakarta. PT. Raja Grafindo Persada. 33-43.

[13] Harjaka, T, Martono, E, Witjaksono, and Sunarminto, B.H. 2015. Potential Mushroom Metarhizium anisopliae For Urethral Control of Sugar Cane Root. National Seminar of Pesnab IV. 91-98.

[14] Hashim, A, Nuraida, and Trizelia. 2009. Pathogenicity of Entomopathogenic Fungi Against Stadia Egg and Pest Larvae Cabbage Crocidolomia pavonana Fabricuius. Journal of Horticulture 12:45-49. ISSN 0853-7097.

[15] Heriyanto and Suharno. 2008. Pathogenic Studies Metarhizium anisopliae (Meth.) Sor ResultsLong Liquid Natural Medium on Oryctes rhinoceros Larvae. J. Agricultural Sciences 4 (1): 47-54. 
[16] Islam, M.T and Omar, D.B. 2015. Combined Effect of Beauveria bassiana With Neem on Virulence of Insect in Case of Two Application Approaches. The Journal of Animal \& Plant Sciences 22. (1): 77-82.

[17] Junaedi D, Bakti, D and Zahara, F. 2015. Predation Power Myopopone castaneae (Hymenoptera: Formicidae) Against Larvae Oryctes rhinoceros L. (Coleoptera: Scrabaidae) at the Laboratory. Journal of Agroecotechnology 3 (1): 112-117. ISSN 2337-6597.

[18] Kaur, S, Kaur, HP, Kaur K, and Kaur A. 2011. Effect of Different Concentrations of Beauveria bassiana on Development and Reproductive Potential of Spodoptera litura (Fabricius). Journal of Biopesticides 4 (2): 161-168.

[19] Khairunnisa, S, Pinem, MI, and Zarah, F. 2014. Effectiveness Test of Entomopatogen Nematodes as Controlling Borrow Oil Borrow (Oryctes rhinoceros L.) (Coleoptera: Scarabaidae) in the Laboratory. Journal of Agroecotechnology 2 (2): 607-620. ISSN 2337-6597.

[20] Kaszak, BD. 2014. Cordyceps fungi as natural killers, new hopes for medicine and biological control factors. Ann. Parasitol 60 (3): 151-158.

[21] Koto, RG. 2013. In Vitro Digestibility of Dry Ingredients and Organic Ingredients of Maize Straw (Zea mays) Inoculated with Trichoderma sp On Different Different Incubations. 8-15. Essay.

[22] Latifian, M, Rad, B, Amani, M, Rahkhodaei, E. 2013. Mass Production of Entomopathogenic Fungi Beauveria bassiana (Balsamo) by Using Agricultural Products Based on Liquid- Solid Diphasic Method for Date Palm Pest Control. International Journal of Agriculture and Crop Sciences 5 (9): 23337-2341.

[23] Manurung, EM, Tobing, MC, Lubis, L and Priwiratama, H. 2012. Efficacy of Metarhizium anisopliae Formulations Against Oryctes rhinoceros L. Larvae (Coleoptera: Scrabaeidae) at the Insectarium. Journal of Agroecotechnology 1 (1): 47-63.

[24] Mudroncekova, S., Mazan, M., Nemcovic, M., Salamon, I. 2013. Entomopathogenic Fungus Species Beauveria bassiana (Bals.) and Metarhizium anisopliae (Metsch.) Used as Mycoinsecticide Effective in Biological Control of Ips Typographus (L.). Journal of Microbiology, Biotechnology and Food Sciences 2 (6): 2469-2472.

[25]Mustafa, Z. 2011. Effect of Trichoderma spp Application on Rhizoctonia solani Bee Disease in Robusta Seedlings. Thesis.6-9.
[26] Niken. 2009. Trichoderma Viridae Know More. http://ayyaa.multiply.com/journal. Retrieved January 10, 2013.

[27] Pahan, 2008. Complete Guide to Palm Oil. SelfHelping Spreader, Jakarta. 410 p.

[28] PPKS Palm Oil Research Center. 2009. Technical Meeting on Oil Palm. Research Center for Oil Palm. Field

[29] Rosmini and Lasmini, S.A. 2010. Identification of Local Entomopathogen Fungi and Its Pathogenicity Level against Green Planthopper Pest (Nephotettix virescens Distant.) Tungro Virus Vector On Rice Field Crops in Donggala District. Journal of Agroland 17 (3): 207-212. ISSN: 0854 - 641X.

[30] Salbiah, D., Laoh, JH, and Nurmayani. 2013. Test Several Doses of Beauveria bassiana vuillemin Against Pest Larvae Horn Beetle Oryctes rhinoceros (Coleoptera: Scarabaeidae) On Palm Oil. Journal of Applied Science Sciences (2): 137-142. ISSN 20875428.4 .

[31] Saputra, D.D., Mudjiono, G and Afandhi, A. 2013. Addition of Vinegar to Increase Production of Conidia, Sprout and Patogenicity of Beauveria bassiana Balsamo (Deuteromycetes: Moniliales) Fungi. Journal of Plant Pests 1 (3): 60-66.

[32] Sihombing, R.H., Oemry, S and Lubis, L. 2014. Effectiveness Test of some Entomopatogenes on Oryctes rhinoceros larvae (Coleoptera: Scrabaeidae) in the Laboratory. Journal of Agroecotechnology (2): 1300-1309. ISSN 2337-6597.4.

[33] Sodiq, M. 2009. Plant Resistance Against Pests. 55-75.

[34] Suprayogi, Marheni and Oemry, S. 2015. The Effectiveness Test of Entomopathogenic Fungus Beauveria bassiana and Metarhizium anisopliae on Green Ladybugs (Hemiptera L.) (Hemiptera, Pentatomidae) on Soybean Plants (Glycine max L.) at Green House. Journal of Agroetechnology 3 (1): 320327.

[35] Suriadi, 2015. Effect of Entomopathogenic Fungus Trichoderma sp. against the Black Ladybug Mortality (Paraeucosmetus pallicornis Dallas) on Rice Plant. 68. Essay.

[36] Surtikanti and Yasin, M. 2009. Entomopatogenic Effectiveness of Beauveria bassiana Vuill. from Various Growing Media to Spodoptera litura F. (Lepidoptera: Noctuidae) in Laboratory. Proceedings of the National Seminar on Cereals. 358-362.

[37] Suziani W. 2011. Test Pathogenitas Mushrooms Metarhizium anisopliae and Mushroom Cordyceps 
militarist Against the Borrowing Shoot larvae (Oryctes

rhinoceros) (Coleoptera; Scarabaeidae) at the

Laboratory. Essay. Faculty of Agriculture, University

of North Sumatra, Medan.

[38] Tampubolon DY, Y Pangestiningsih, F Zahra and F

Manik. 2013. Pathogenicity Test of Bacillus

thuringiensis and Metarhizium anisopliae Against

Mortality Spodoptera litura Fabr (Lepidoptera:

Noctuidae) at Laboratory. Journal of

Agroecotechnology 1 (3): 784-791.

[39] Tarigan B, Syahrial and Tarigan MU. 2013. Effectiveness Test Beauveria bassiana and Bacillus thuringiensis Against Fireworm (Setothosea asigna Eeck, Lepidoptera, Limacodidae) at the Laboratory. Journal of Agroecotechnology 1 (4): 1439-1446. ISSN 2337-6597.

[40] Trizelia Syahrawati M, Mardiah A. 2011. Pathogenicity of several Isolate Fungi Entomopatogen Metarhizium spp. Against Egg Spodoptera litura Fabricius (Lepidoptera: Noctuidae). Entomology Association of Indonesia 8 (1): 45-54.

[41] Trizelia Armon A, Jailani H. 2015. The diversity of entomopathogenic fungi in the rhizosphere of various vegetable crops. Proceedings of Indonesian Biodiversification Society Seminar. 1. (5) .998-1004. DOI 10.13057 / psnmbi / m010 307.

[42] Utomo and Pardede. 2014. Effect of seasons on Hypobiose Haemonchuscontortus and Population Fluctuation of Sheep Digestive Nematodes in Indramayu, West Java. Proceedings of Seminar. National Research Results of Higher Education. 171192.

[43] Yuniar, W. 2013. Screening and Identification of Selulolotok Kapang on Vermicomposting Process of Oil Palm Empty Bunches (TKKS). Thesis.4-10.

[44] Yustina Fauziah Y, and Rika S. 2012. Population Structure of Horn Beetle (Oryctes rhinoceros) in Oil Palm Plantation Area of Kenantan Village, KamparRiau Regency. Journal of Biogenesis 8 (2): 55-63. 